\title{
OBITUARY
}

\section{Ioannis Vardoulakis}

Professor Ioannis Vardoulakis died at the age of 60 as a result of an accident he had at home. On 6 September 2009 he sustained extensive cranio-cerebral injuries after falling from a height. Despite extensive surgery he never regained consciousness; he eventually passed away peacefully in hospital on 19 September.

Ioannis Vardoulakis was born on 22 March 1949 in Chania, Crete, in Greece. After graduating from the German School of Athens he was admitted to the Faculty of Civil Engineering of the National Technical University of Athens (NTUA), from where he graduated in 1972 with a 5-year diploma of civil engineering in structural engineering. He immediately started a $\mathrm{PhD}$ in soil mechanics at the University of Karlsruhe, in Germany, which he obtained in 1977 'Mit Auszeichnung' (with the highest honours). Three years later, in 1980, he took up his first academic post as an Assistant Professor in the Department of Civil Engineering of the University of Minnesota, USA. He progressed to Associate Professor in 1983 and Professor of Geomechanics in 1986. In 1990 he returned to NTUA, where up until his untimely death he was Professor of Mechanics at the Department of Mechanics, in the School of Applied Mathematical and Physical Sciences.

Ioannis Vardoulakis was an internationally leading researcher in the field of geomechanics. His range of expertise was very wide; he made major contributions in experimental and computational geomechanics, constitutive modelling, bifurcation and localisation theory, liquefaction, fluidisation and internal erosion, and multiphase flow in granular media.

Failure of geomaterials associated with the onset of deformation localisation was one of his core research interests from the start of his career and it was at the heart of many of his experimental investigations. He devised a number of novel experimental apparatuses that allow the free formation of localisation bands and the measurement of their stressdeformation characteristics; for these he received five patents (four US and one French). On the theoretical front he was among the first to introduce and widely use bifurcation analysis in the study of shear-banding and geomaterial failure in general - a research area that he progressively made his own. Having recognised that robust modelling of strain softening materials requires the introduction of material parameters corresponding to microstructural length scales, he was at the forefront of developing and using continuum theories with microstructure, such as variants of gradient plasticity or of the Cosserat continuum, to model the development of shear bands and the spontaneous emergence and evolution of instabilities in softening soils and rocks.

Especially after returning to NTUA in 1990, his research interests broadened to encompass liquefaction and fluidisation, and also phenomena of internal erosion, where his novel theory for the production of sand particles from hydrocarbon-producing wells is now widely accepted by the

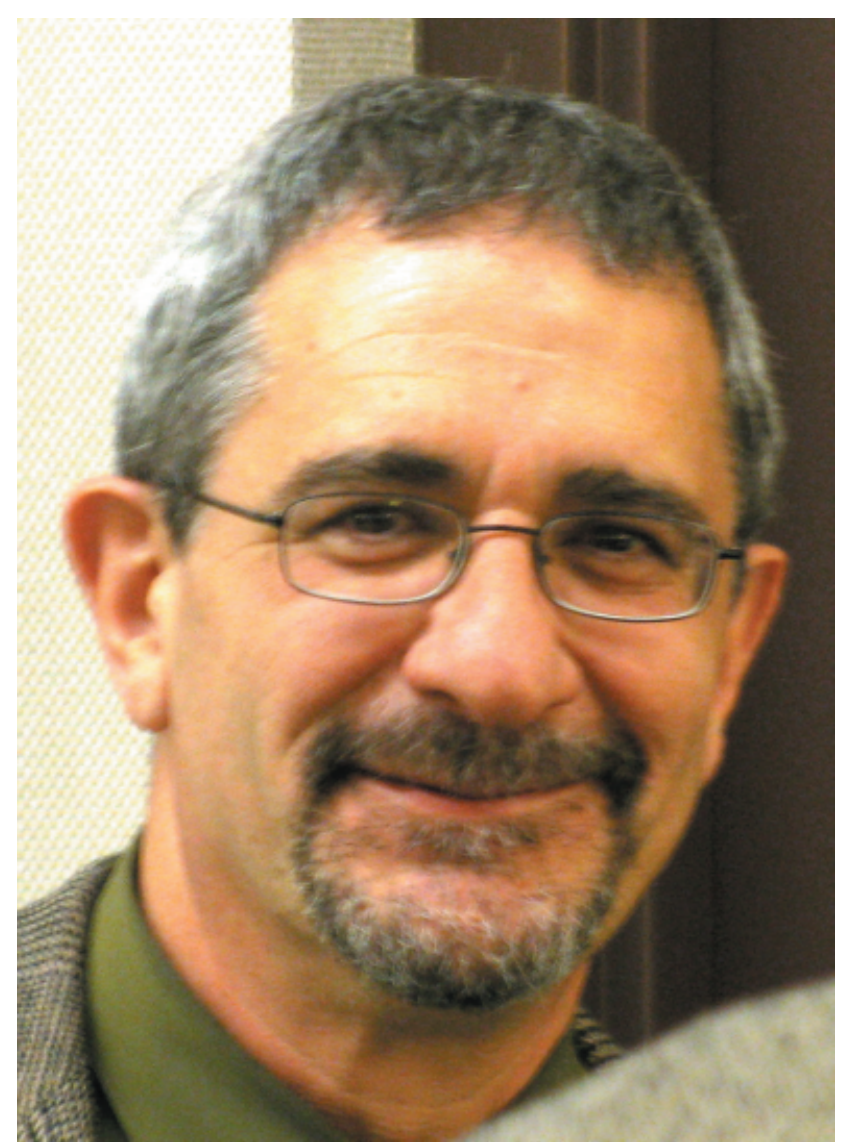

Ioannis Vardoulakis, 1949-2009 (photograph courtesy of Professor T. Hueckel)

petroleum engineering industry as the basis of a rational approach to the problem. More recently, having turned his attention to coupled multi-physics problems, he developed a seminal thermo-poro-mechanical theory for the evolution of catastrophic landslides and earthquakes. With this application in mind, understanding and quantifying the mechanisms behind the generation of heat in rapidly deforming soils was one of the areas he had focused on during the last few months before his untimely death.

Ioannis Vardoulakis's research was visionary but pertinent, as also shown by the large number of grants he received in its support over the years from a variety of national and international funding bodies and from industry. His latest achievement was the award of a prestigious, substantial 5year grant from the European Research Council through the IDEAS programme, to investigate the 'Mechanics of energy dissipation in dense granular materials'. He had a very 
strong publication record, having (co)-authored over 140 papers in refereed research journals and the well-known, unique of its kind monograph 'Bifurcation analysis in geomechanics' (Vardoulakis \& Sulem, 1995). His publications have attracted over 3000 citations, while his seminal Géotechnique paper on 'The thickness of shear bands in granular materials' (Mühlhaus \& Vardoulakis, 1987) is, with 359 citations, the second most-cited paper in the history of this journal. In 1996 he was awarded the Bishop medal by the ICE, while in 2002 he was awarded the Medal of the Japanese Geotechnical Society for 'outstanding contributions to geomechanics'

Ioannis Vardoulakis was highly active in the international geomechanics arena. He was Chair of the Technical Committee 34 (TC34) on 'Prediction and simulation methods in geomechanics'; of the ISSMGE between 1998-2001 and a core member since. He had been a core member of the 'ALERT Geomaterials' network since 1993, contributing actively in the network's effort to develop a European School of Thinking in the field of the mechanics of geomaterials and leading many of the network's activities over the years. He also served as general secretary of the Hellenic Society for Theoretical and Applied Mechanics between 2003 and 2006 and as vice president since 2007. He was a soughtafter speaker and, in the past 10 years alone, he delivered 17 invited presentations at internationally established conferences, he organised and/or lectured at seven advanced schools, and he was an invited scholar to four different academic institutions of international standing. His expert opinion was in equally high demand; he was reviewer for 30 international research journals and 17 national and international organisations.

In addition to being a highly successful researcher, Ioannis Vardoulakis was a dedicated teacher who held good teaching in high esteem. His teaching was rigorous, seminal and of a high standard. For example, he did not hesitate to introduce the ideas of the Timoshenko beam or to teach buckling as a bifurcation problem in first-year undergraduate courses. Where he felt that students perhaps lacked the mathematical background to follow his lectures, he would timetable additional tutorials in his own time rather than adapt the level at which he taught. This uncompromising attitude made his lectures a pleasure to follow and served as inspiration for many of the students who later went on to work with him as researchers. At the graduate level he is remembered for his systematic, cutting-edge lectures on subjects ranging from continuum mechanics and bifurcation theory to plasticity and thermo-poro-mechanics at NTUA, the Doctoral Schools of ALERT, CISM, LARAM and elsewhere.

As a PhD advisor, Ioannis Vardoulakis was exemplary. He was never short of demanding, original problems to be tackled and he was always happy to entrust such problems to his $\mathrm{PhD}$ students, actively encouraging them to take initiative and pursue their own ideas about how to solve them, or about what the important questions to ask next were. He deeply believed in the benefits of collaboration with other internationally leading researchers, and he went to great lengths to offer his students appropriate opportunities through collaborative projects, bilateral agreements or any other mechanism that could be found. He generously took time to discuss with his students problems and offer advice, guidance, parallels from Greek philosophers and inspired maxims. Phrases such as 'Do not worry because you may not even need to worry', 'Difficult is only what we do not know' and 'I don't understand the word "believe": either you know or you don't' continue to inspire all who worked with him. He advised to completion 14 doctoral students, six of whom are already members of academic staff in universities around the world.
Ioannis Vardoulakis is survived by his wife Tania, his daughter Katia and his son Pavlos.

M. Stavropoulou and A. Zervos

\section{BIBLIOGRAPHY}

Alonso-Marroquin, F., Luding, S., Herrmann, H. J. \& Vardoulakis, I. (2005). Role of anisotropy in the elastoplastic response of a polygonal packing. Phys. Rev. E 71, Art. No. 051304

Bardet, J.-P. \& Vardoulakis, I. (2001). The asymmetry of stress in granular media. Int. J. Solids Structs, 38, No. 2, 353-367.

di Prisco, C., Imposimato, S. \& Vardoulakis, I. (2000). Mechanical modelling of drained creep triaxial tests on loose sand. Géotechnique 50, No. 1, 73-82, doi: 10.1680/geot.2000.50.1.73.

Drescher, A. \& Vardoulakis, I. (1982). Geometric softening in triaxial tests on granular material. Géotechnique 32, No. 4, 291-303, doi: 10.1680/geot.1982.32.4.291.

Froiio, F., Tomassetti, G. \& Vardoulakis, I. (2006). Mechanics of granular materials: the discrete and the continuum descriptions juxtaposed. Int. J. Solids Structs 43, No. 25-26, 7684-7720.

Han, C. \& Vardoulakis, I. G. (1991). Plane-strain compression experiments on water-saturated fine-grained sand. Géotechnique 41, No. 1, 49-78, doi: 10.1680/geot.1991.41.1.49.

Hettler, A. \& Vardoulakis, I. (1984). Behavior of dry sand tested in a large triaxial apparatus. Géotechnique 34, No. 2, 183-198, doi: 10.1680 /geot.1984.34.2.183.

Mühlhaus , H-B. \& Vardoulakis, I. (1987). The thickness of shear bands in granular materials. Géotechnique 37, No. 3, 271-283, doi: 10.1680 /geot.1987.37.3.271.

Ord, A, Vardoulakis, I. \& Kajewski, R. (1991). Shear band formation in Gosford sandstone. Int. J. Rock Mech. Miner. Sci. 28 , No. 5, 397-409.

Stavropoulou, M., Papanastasiou, P. \& Vardoulakis, I. (1998). Coupled wellbore erosion and stability analysis. Int. J. Numer. Analyt. Meth. Geomech. 22, No. 9, 749-769.

Sulem, J., Vardoulakis, I., Ouffroukh, H., Boulon, M. \& Hans, J. (2004). Experimental characterization of the thermo-poro-mechanical properties of the Aigion fault gouge. C. R. Geoscience 336, No. 4-5, 455-466.

Sulem, J., Vardoulakis, I., Papamichos, E., Oulahna, A. \& Tronvoll, J. (1999). Elasto-plastic modelling of Red Wildmoor sandstone. Mech Coh. Frict. Mater. 4, No, 3, 215-245.

Vardoulakis, I. (1980). Shear band inclination and shear modulus of sand in biaxial tests. Int. J. Numer. Analyt. Meth. Geomech. 4, No. 2, 103-119.

Vardoulakis, I. (1996). Deformation of water saturated sand: I. Uniform undrained deformation and shear banding. Géotechnique 46, No. 3, 441-456, doi: 10.1680/geot.1996.46.3.441.

Vardoulakis, I. (1996). Deformation of water saturated sand: II. The effect of pore-water flow and shear banding. Géotechnique, 46, No. 3, 457-472, doi: 10.1680/geot.1996.46.3.457.

Vardoulakis, I. (2002). Dynamic thermo-poro-mechanical analysis of catastrophic landslides. Géotechnique 52, No. 3, 157-171, doi: $10.1680 /$ geot.2002.52.3.157.

Vardoulakis, I. \& Aifantis, E. C. (1991). A gradient flow theory of plasticity for granular materials. Acta Mechanica 87, No. 3-4, 197-217.

Vardoulakis, I, Exadaktylos, G. \& Aifantis, E. (1996). Gradient elasticity with surface energy: mode-III crack problem. Int. J. Solids Structs 33, No. 30, 4531-4559.

Vardoulakis, I., Goldscheider, M. \& Gudehus, G. (1978). Formation of shear bands in sand bodies as a bifurcation problem. Int. J. Numer. Analyt. Meth. Geomech. 2, No. 2, 99-128.

Vardoulakis, I. \& Graf, B (1985). Calibration of constitutive models for granular materials using data from biaxial experiments. Géotechnique 35, No. 3, 299-317, doi: 10.1680/geot.1985.35.3. 299.

Vardoulakis, I. \& Sulem, J. (1995). Bifurcation analysis in geomechanics. Blackie Academic and Professional.

Veveakis, E., Vardoulakis, I. \& Di Toro, G. (2007). Thermo-poromechanics of creeping landslides: the 1963 Vaiont slide, Northern Italy. J. Geophys. Res. 112, F03026.

Zervos, A., Papanastasiou, P. \& Vardoulakis, I. (2001). A finite element displacement formulation for gradient elastoplasticity. Int. J. Numer. Meth. Engng 50, No. 6, 1369-1388. 